\title{
Sporolituus thermophilus gen. nov., sp. nov., a citrate-fermenting thermophilic anaerobic bacterium from geothermal waters of the Great Artesian Basin of Australia
}

\author{
Christopher D. Ogg and Bharat K. C. Patel
}

Correspondence

Bharat K. C. Patel

b.patel@griffith.edu.au

\author{
Microbial Gene Research and Resources Facility, School of Biomolecular and Physical Sciences, \\ Griffith University, Brisbane, OLD 4111, Australia
}

The Great Artesian Basin (GAB) underlies more than onefifth of the Australian continent $\left(1.7 \times 10^{6} \mathrm{~km}^{2}\right)$ and, with a water-storage capacity of $8.7 \times 10^{12} \mathrm{~m}^{3}$, is the world's largest geothermal subsurface aquifer (Habermehl, 1980). The GAB was formed between 100 and 250 million years ago and is composed of multiple alternating layers of water-bearing permeable sandstone aquifers and nonwater-bearing impermeable shale strata. The water flows from the recharge areas at the edge of the basin to the discharge areas in central Australia as mound springs, at an estimated rate of $1-5 \mathrm{~m}$ year ${ }^{-1}$. The Earth's magma heats these slow-flowing subsurface waters up to $100{ }^{\circ} \mathrm{C}$ depending on the depth of the water-bearing layer. The high temperatures and the geological formations surrounding the aquifer affect the chemistry and local chemical composition of the bicarbonate-, chloride-, sulfate- or

Abbreviation: GAB, Great Artesian Basin.

The GenBank/EMBL/DDBJ accession number for the 16S rRNA gene sequence of strain $\mathrm{AeG}^{\top}$ is FJ169187. iron-rich GAB groundwaters. Some 5000 free-flowing bores tap the GAB and provide a vital water supply to outback communities for agricultural, industrial and domestic purposes. The bores can be $3000 \mathrm{~m}$ deep and source temperatures can range between 30 and $100{ }^{\circ} \mathrm{C}$, depending on the bore depth. The chemistry, temperature and slow flow rate of the deep subsurface and the surface groundwaters in the runoff channels formed from the freeflowing bores provide a conducive environment for a diverse range of micro-organisms to thrive. For example, culture-independent analyses of four microbial mat communities colonizing the New Lorne bore (registered bore number 17263) runoff channel at temperatures ranging from 52 to $75{ }^{\circ} \mathrm{C}$ identified species spanning the full spectrum of the domain 'Bacteria', including a diverse range of currently uncultured novel organisms (Spanevello, 2001). Similarly, culture-dependent studies have isolated numerous novel thermophilic and mesophilic microorganisms, including sulfate-reducers (Love et al., 1993; Redburn \& Patel, 1994), carbohydrate-fermenters 
(Andrews \& Patel, 1996), strict aerobes (Kanso \& Patel, 2003; Spanevello et al., 2002) and metal-reducers (Ogg \& Patel, 2009a, b, c; Kanso et al., 2002). Most culturedependent studies of subsurface environments, including ours, have focused largely on the isolation of carbohydratefermenting and metal- or sulfur-compound-reducing organisms, perhaps due to the potential commercial value of their thermostable enzymes, and their potential applications in microbial-enhanced oil recovery and bioremediation processes (Haki \& Rakshit, 2003; Head et al., 2003; Lazar et al., 2007; Lovley, 2001). In this report, the properties of a novel thermophilic, citrate-fermenting, strictly anaerobic bacterium, designated strain $\mathrm{AeG}^{\mathrm{T}}$, were investigated. An isolate with an almost identical $16 \mathrm{~S}$ rRNA gene sequence ( $>99 \%$ ) was also cultured from the outflow of another GAB bore (registered bore number 22981).

A sample of a green microbial mat thriving at $57{ }^{\circ} \mathrm{C}$ was collected from New Lorne Bore, situated near Blackall, some $970 \mathrm{~km}$ north-west of Brisbane, Queensland, Australia (24 $54^{\prime} 48^{\prime \prime} \mathrm{S} 145^{\circ} 08^{\prime} 18^{\prime \prime} \mathrm{E}$ ) (Spanevello et al., 2002) and water samples from another bore (registered bore number 22981), situated at Mitchell, approximately $570 \mathrm{~km}$ west-north-west of Brisbane and $400 \mathrm{~km}$ southwest of Blackall were also collected. Bore 22981 is $403 \mathrm{~m}$ deep and has a source temperature of $46{ }^{\circ} \mathrm{C}$. Sulfatereducers, carbohydrate-fermenters and species of the genus Meiothermus have been isolated previously from samples from both bores (Spanevello \& Patel, 2004).

Enrichments for iron-reducers were performed in an aerobic medium designated APL medium. APL medium contained (per 1 deionized water): $1 \mathrm{~g} \mathrm{NH}_{4} \mathrm{Cl}, 0.6 \mathrm{~g}$ $\mathrm{K}_{2} \mathrm{HPO}_{4}, \quad 0.3 \mathrm{~g} \quad \mathrm{KH}_{2} \mathrm{PO}_{4}, \quad 0.1 \mathrm{~g} \quad \mathrm{MgCl}_{2} .6 \mathrm{H}_{2} \mathrm{O}, \quad 0.1 \mathrm{~g}$ $\mathrm{CaCl}_{2} \cdot 2 \mathrm{H}_{2} \mathrm{O}, 1.0 \mathrm{~g} \mathrm{NaCl}, 12.0 \mathrm{~g}$ HEPES, $1 \mathrm{ml}$ vitamin solution (Wolin et al., 1963), $1 \mathrm{ml}$ trace element solution (Zeikus et al., 1979), $1 \mathrm{ml} 0.2 \%$ resazurin, $0.2 \mathrm{~g}$ yeast extract and $2.0 \mathrm{~g}$ ammonium iron (III) citrate (brown in colour). The $\mathrm{pH}$ of the medium was adjusted to 7.2 with $1 \mathrm{M} \mathrm{NaOH}$ and $1 \mathrm{M} \mathrm{HCl}$. APL medium $(9.5 \mathrm{ml})$ was distributed in McCartney bottles and autoclaved for $30 \mathrm{~min}$ at $121{ }^{\circ} \mathrm{C}$ and a pressure of $1.0-1.5 \mathrm{~kg} \mathrm{~cm}^{-2}$ (98$147 \mathrm{kPa}$ ). APL medium that was rendered anoxic by heating for $10 \mathrm{~min}$ in an autoclave at $121{ }^{\circ} \mathrm{C}$ and 1.0 $1.5 \mathrm{~kg} \mathrm{~cm}^{-2}$ to remove dissolved oxygen and subsequently cooled under a stream of oxygen-free nitrogen gas was designated PL medium. Vitamins and trace elements were added and $9.3 \mathrm{ml}$ medium was dispensed into Hungate tubes under oxygen-free nitrogen gas and sterilized for 20 min at $121{ }^{\circ} \mathrm{C}$ and $1.0-1.5 \mathrm{~kg} \mathrm{~cm}^{-2}$.

Enrichment was performed by adding a $500 \mu \mathrm{l}$ sample to $9.5 \mathrm{ml}$ APL medium amended with yeast extract $(0.2 \%)$ followed by incubation at $50{ }^{\circ} \mathrm{C}$. After 3 days incubation, a slimy surface layer was observed in the upper portion of the APL medium suggesting aerobic growth and the medium, which was originally reddish-brown in colour due to the presence of iron (III) oxide, was colourless and a dark precipitate $[\mathrm{Fe}(\mathrm{II})]$ had formed which settled to the bottom, inferring $\mathrm{Fe}(\mathrm{III})$ reduction. On inversion of the enrichment culture, the medium became oxygenated and the colourless medium changed to pink due to the presence of resazurin. This enrichment was then subcultured several times in PL media that had been fortified with a high concentration of yeast extract $(0.2 \%)$ or contained a low concentration of yeast extract $(0.02 \%)$. The enrichments were subsequently serially diluted in PL media with the respective high and low yeast extract concentrations and incubated under the same conditions; the tube containing the lowest serial dilution was selected and the procedure was repeated at least three times. An isolate purified by the serial end-point dilution method in PL medium amended with low concentrations of yeast extract was designated strain $\mathrm{AeG}^{\mathrm{T}}$. The purity of strain $\mathrm{AeG}^{\mathrm{T}}$ was confirmed by microscopy and 16S rRNA gene sequencing and the culture was stored in a glycerol/PL medium $(50: 50)$ mixture at $-20{ }^{\circ} \mathrm{C}$. Pure cultures from PL medium containing high yeast extract enrichments were obtained using the agar shake method. For this, PL medium fortified with $0.2 \%$ yeast extract and $1 \%$ Gelrite was inoculated with a $0.1 \mathrm{ml}$ sample of the lowest serial dilution enrichment culture. Colonies that had developed in PL medium containing high yeast extract after 3 days incubation at $50{ }^{\circ} \mathrm{C}$ were picked and an isolate designated 142 was selected for further studies. Subsequent $16 \mathrm{~S}$ rRNA gene sequencing and sequence comparisons of $1467 \mathrm{nt}$ of strain 142 revealed an almost identical (similarity value $>99 \%$ ) sequence to that of strain $\mathrm{AeG}^{\mathrm{T}}$. Strain 142 also exhibited identical morphological characteristics to strain $\mathrm{AeG}^{\mathrm{T}}$ and so no further characterization tests were performed on this strain. A third isolate, obtained by streaking medium $\mathrm{D}$ agar plates (Brock \& Freeze, 1969), from a sample taken from the surface layer of the initial enrichment culture was designated strain Md-G. 16S rRNA gene sequence analyses and phenotypic studies identified strain $\mathrm{Md}-\mathrm{G}$ as a species of the genus Anoxybacillus; a report on the characterization of strains 142 and Md-G will be presented elsewhere. The characterization of strain $\mathrm{AeG}^{\mathrm{T}}$ is presented in this report.

In parallel, an attempt to enrich for aromatic-oxidizing, $\mathrm{Fe}$ (III)-reducing thermophiles was made by inoculating $700 \mu \mathrm{l}$ water from bore 22981 into $9.3 \mathrm{ml} \mathrm{PL}$ medium amended with $4 \mathrm{mM}$ cinnamate followed by incubation at $50{ }^{\circ} \mathrm{C}$. After 4 days incubation, $\mathrm{Fe}(\mathrm{III})$ reduction was observed and the culture was purified by the repeat endpoint serial dilution method as described above; the pure culture was designated strain 27. Although 16S rRNA gene sequencing and gene analysis of $1501 \mathrm{nt}$ of strain 27 revealed an almost identical (similarity value $>99 \%$ ) $16 \mathrm{~S}$ rRNA gene sequence to that of strain $\mathrm{AeG}^{\mathrm{T}}$, further characterization of this strain has yet to be carried out.

Morphology of cells of strain $\mathrm{AeG}^{\mathrm{T}}$ was determined by phase-contrast microscopy and electron microscopy (Kanso \& Patel, 2003). Cells were sluggishly motile, peritrichously flagellated, curved rods $(2.0-10.0 \times 0.8-$ $1.0 \mu \mathrm{m})$, which existed singly and in short chains and readily formed spores in all media tested. Cells of strain 
$\mathrm{AeG}^{\mathrm{T}}$ stained Gram-negative and electron micrographs of thin sections confirmed a Gram-negative cell-wall ultrastructure consisting of an inner electron-dense layer adjacent to the cell membrane and an outer electron-light layer consisting of regular protein subunits (Fig. 1).

Unless otherwise indicated, all growth experiments were conducted at least twice and cultures were subcultured at least once in the same medium prior to the start of the experiment. Growth studies were performed in a modified anaerobic tryptone-yeast extract-glucose (TYEG) medium, designated TYECit medium, which consisted of lowphosphate-buffered salts (LPBS) amended with $0.2 \%$ each of tryptone, yeast extract and citrate (in the place of glucose). TYECit medium was prepared anaerobically as described previously (Patel et al., 1985a, b). Growth was measured at $580 \mathrm{~nm}$ by inserting Hungate tubes directly into a modified cuvette holder of a Novaspec LKB spectrophotometer (Pharmacia Biotech). Growth of strain $\mathrm{AeG}^{\mathrm{T}}$ was tested at $26-70{ }^{\circ} \mathrm{C}$ and $\mathrm{pH}$ 5.0-10.0. Strain $\mathrm{AeG}^{\mathrm{T}}$ grew optimally in TYECit medium at $55{ }^{\circ} \mathrm{C}$ (range: $45-$ $60{ }^{\circ} \mathrm{C}$ ) and $\mathrm{pH} 7.0$ (range: $\mathrm{pH} 6.5$ and 8.0).

To investigate the effect of each specific energy substrate present in TYECit medium (yeast extract, tryptone and citrate) on growth, each carbon source was added to LPBS medium individually and in combination and growth was monitored. No growth of strain $\mathrm{AeG}^{\mathrm{T}}$ was observed in LPBS amended with $0.2 \%$ tryptone (medium T), $0.2 \%$ yeast extract (medium YE), $0.2 \%$ each of tryptone and yeast extract (medium TYE), or on $0.2 \%$ citrate as the sole carbon source. Growth only occurred in LPBS medium containing $0.2 \%$ each of citrate and tryptone (TCit medium) and LPBS medium containing $0.2 \%$ each of citrate and yeast extract (YECit medium), where optical densities after $25 \mathrm{~h}$ incubation reached approximately 75 and $83 \%$, respectively, of those obtained in TYECit medium $\left(\mathrm{OD}_{580 \mathrm{~nm}}\right.$ of 0.19 taken as $\left.100 \%\right)$. When yeast extract concentrations were lowered in YECit medium to
$0.02 \%$ and $0.05 \%$, approximately $35 \%$ and $20 \%$ less growth was observed, respectively, after $25 \mathrm{~h}$ incubation and approximately equal growth was observed with $0.1 \%$ yeast extract compared with $0.2 \%$ yeast extract $\left(\mathrm{OD}_{580}\right.$ of 0.16 taken as $100 \%)$. This suggests that yeast extract increases the growth rate of strain $\mathrm{AeG}^{\mathrm{T}}$ in the presence of citrate in a dose-dependent manner up to $0.1 \%$. Strain $\mathrm{AeG}^{\mathrm{T}}$ was unable to grow under aerobic conditions in medium D (Brock \& Freeze, 1969), medium D amended with citrate $(0.2 \%)$ or in aerobic YECit medium.

Substrate utilization tests were performed in LPBS medium supplemented with $0.02 \%$ and $0.1 \%$ yeast extract (YE medium). Soluble substrates were added from sterile anaerobic stock solutions to a final concentration of $0.2 \%$. Insoluble substrates were weighed directly into Hungate tubes and the medium was dispensed and then sterilized. Growth $\left(\mathrm{OD}_{580}\right)$ was measured three times a day until stationary phase was reached. Cultures amended with citrate were used as positive controls and cultures lacking any additional substrates were used as negative controls. Growth was observed in $0.02 \%$ and $0.1 \%$ YE medium amended with citrate and malate, but not with glucose, galactose, mannose, lactose, cellobiose, rhamnose, xylose, sucrose, ribose, fructose, arabinose, maltose, raffinose, mannitol, inositol, dextrin, starch, pectin, chitin, peptone, glycerol, ethanol, acetate, propionate, succinate, pyruvate, aspartate, formate, Casamino acids or amyl media (Research Achievement).

Sodium thiosulfate $(20 \mathrm{mM})$, sodium sulfate $(20 \mathrm{mM})$, sodium sulfite $(10 \mathrm{mM})$, elemental sulfur $(1 \%)$ and sodium nitrate $(20 \mathrm{mM})$ were tested as electron acceptors in YE medium lacking the reductant $\mathrm{Na}_{2} \mathrm{~S}$ as described by Ramamoorthy et al. (2006) and Ogg \& Patel (2009a). The reduction of $\mathrm{FeCl}_{3}$, amorphous iron (III) oxyhydroxide (Lovley \& Phillips, 1986) and Mn(IV) (Lovley \& Phillips, 1988) were tested at concentrations of $2 \mathrm{~g} \mathrm{l}^{-1}$ in PL medium lacking ammonium iron (III) citrate. Fe(III)

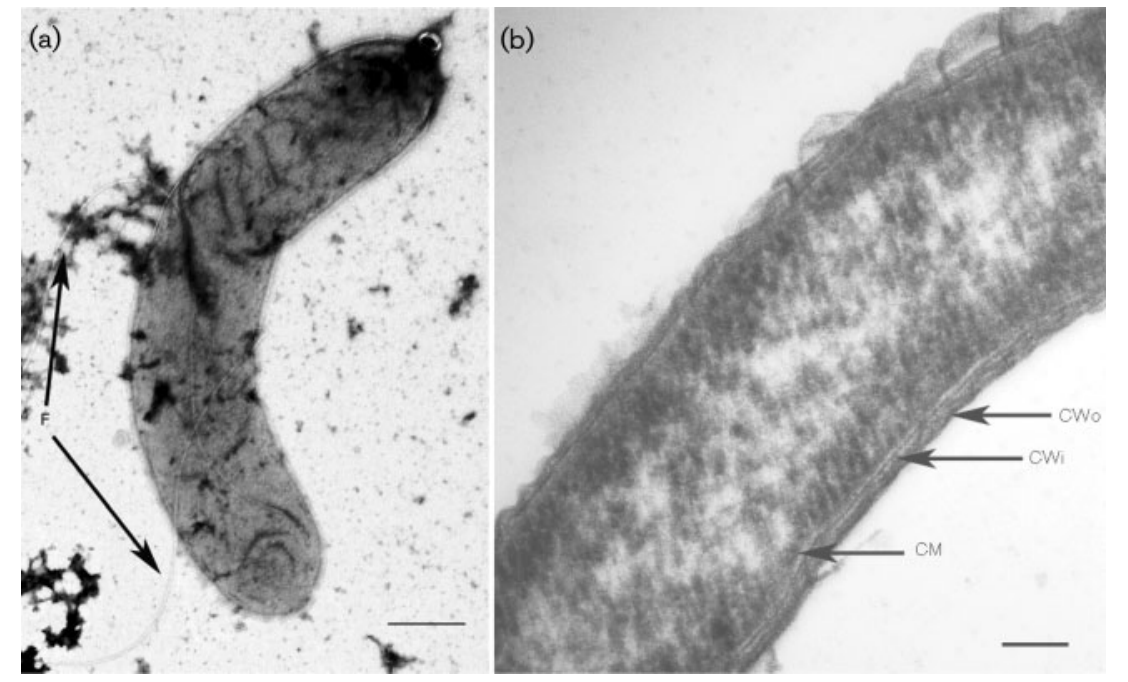

Fig. 1. Electron micrographs of cells of strain $\mathrm{AeG}^{\top}$. (a) Negatively stained cell showing curved cell structure and flagella (F); bar, $500 \mathrm{~nm}$. (b) Transmission electron micrograph of a thin section showing cell-wall ultrastructure revealing the presence of a cytoplasmic membrane (CM), an electron-dense wall layer adjacent to the membrane $(\mathrm{CWi})$ and an outer cell-wall layer (CWo); bar, $100 \mathrm{~nm}$. 
reduction was determined using the ferrozine method (Sørensen, 1982). For this, $0.1 \mathrm{ml}$ sample was mixed with $3 \mathrm{ml}$ ferrozine reagent and, after $1 \mathrm{~min}$, the absorbance at $562 \mathrm{~nm}$ was determined. $\mathrm{Mn}(\mathrm{IV})$ reduction was inferred by a clearing of the media and was further confirmed using the leuco crystal violet manganese oxide detection technique (Spratt et al., 1994). In the presence of yeast extract $(0.2 \%)$, strain $\mathrm{AeG}^{\mathrm{T}}$ was able to reduce thiosulfate and sulfite, but not sulfate, sulfur, nitrate, $\mathrm{FeCl}_{3}$, amorphous iron (III) oxyhydroxide or $\mathrm{Mn}(\mathrm{IV})$. The inability of strain $\mathrm{AeG}^{\mathrm{T}}$ to reduce $\mathrm{FeCl}_{3}$ and amorphous iron (III) oxyhydroxide suggests that citrate is utilized as a carbon source and, therefore, the observed $\mathrm{Fe}(\mathrm{III})$ reduction is a by-product of this metabolism. Growth of strain $\mathrm{AeG}^{\mathrm{T}}$ in TYECit medium without added ammonium iron (III) citrate supported this conclusion.

Antibiotic sensitivity was determined by adding antibiotics from filter-sterilized stock solutions to sterilized TYECit media to final concentrations of 10 and $100 \mu \mathrm{g} \mathrm{ml}^{-1}$. Growth inhibition (\%) of each antibiotic was calculated from final turbidity measurements of cultures that had been grown in antibiotic-free TYECit medium. Strain $\mathrm{AeG}^{\mathrm{T}}$ was completely inhibited ( $100 \%$ inhibition) in the presence of ampicillin, streptomycin, tetracycline, penicillin and chloramphenicol (all at $10 \mu \mathrm{g} \mathrm{m}^{-1}$ ). To test the effect of $\mathrm{NaCl}$ on growth of strain $\mathrm{AeG}^{\mathrm{T}}, \mathrm{NaCl}$ was weighed directly into Hungate tubes and TYECit medium was dispensed and then sterilized. Strain $\mathrm{AeG}^{\mathrm{T}}$ was unable to grow at $\mathrm{NaCl}$ concentrations higher than $1 \%$.

The DNA G $+\mathrm{C}$ content of strain $\mathrm{AeG}^{\mathrm{T}}$ was determined by the thermal denaturation method (Marmur \& Doty, 1962) in a Cintra20 spectrophotometer (GBC Scientific Equipment) with DNA that had been amplified using a TempliPhi Amplification kit (Amersham Biosciences) essentially as described by Ogg \& Patel (2009a). The genomic DNA $\mathrm{G}+\mathrm{C}$ content was calculated to be $55.4 \pm 1.0 \mathrm{~mol} \%$.

16S rRNA gene amplification and sequencing were carried out using the method of Ogg \& Patel (2009a). Phylogenetic analysis of the consensus 16S rRNA gene sequence comprising $1501 \mathrm{nt}$ indicated that strain $\mathrm{AeG}^{\mathrm{T}}$ was a member of the family Veillonellaceae, class 'Clostridia', phylum 'Firmicutes', and was most closely related to Propionispora vibrioides DSM $13305^{\mathrm{T}}$ (90.7\% sequence similarity to type strain) and Propionispora hippei DSM $15287^{\mathrm{T}}$ (90.8\% sequence similarity to type strain) (Fig. 2).

This report describes a modified enrichment strategy aimed at creating a microaerophilic $\mathrm{Fe}(\mathrm{III})$-reducing environment from which a citrate-fermenting bacterium, designated strain $\mathrm{AeG}^{\mathrm{T}}$, was isolated. The isolation of strain 27 from the Mitchell bore sample, which had an almost identical $16 \mathrm{~S}$ rRNA gene sequence ( $>99 \%$ similarity) to that of strain $\mathrm{AeG}^{\mathrm{T}}$, suggests that $\mathrm{AeG}^{\mathrm{T}}$ is perhaps a dominant citrate reducer and is widely dispersed within the $G A B$ subsurface environment. Strain $\mathrm{AeG}^{\mathrm{T}}$ and the two most closely related species based on 16S rRNA gene sequence analysis, i.e. Propionispora vibrioides (Abou-Zeid et al., 2004) and Propionispora hippei (Biebl et al., 2000), isolated from compost and sewage sludge, respectively, are Gramnegative curved rods that readily form terminal endospores and grow at near-neutral $\mathrm{pH}$ levels. However, strain $\mathrm{AeG}^{\mathrm{T}}$ could be differentiated from both species of the genus

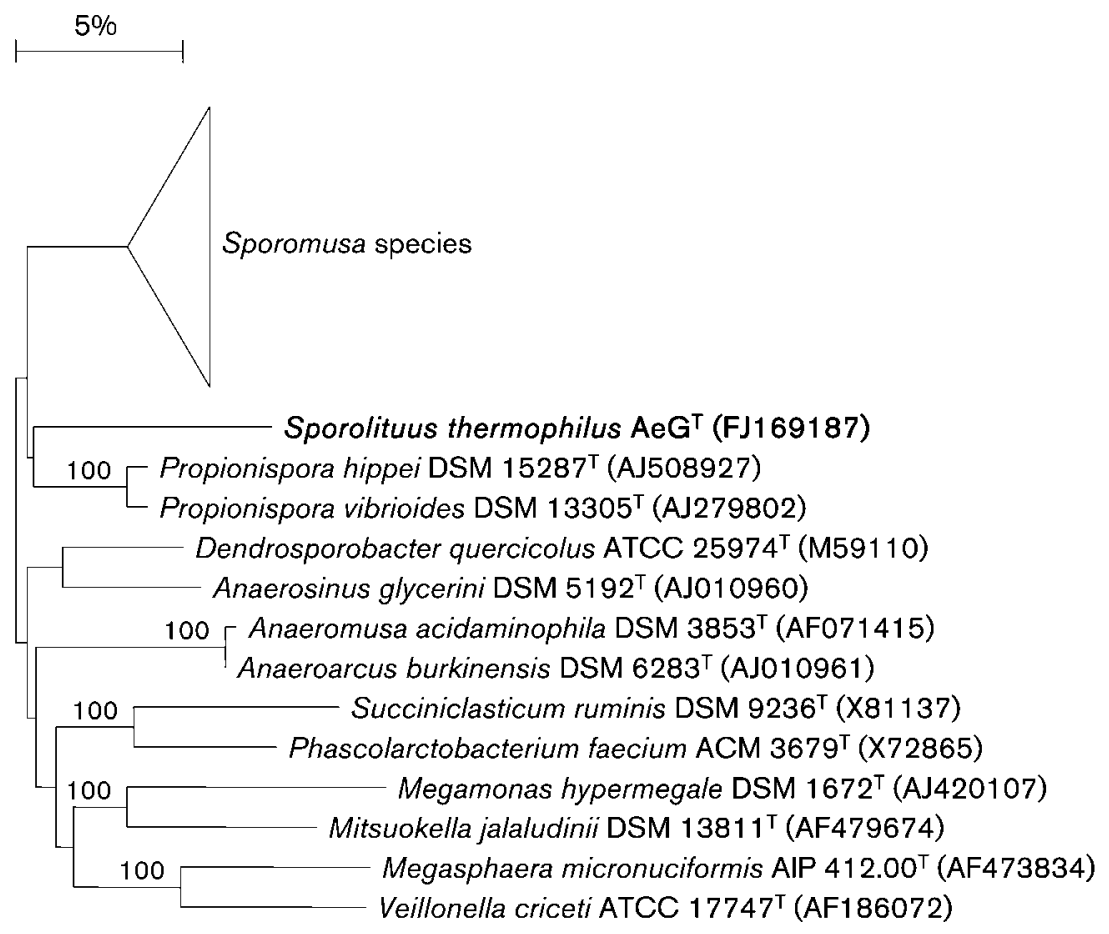

Fig. 2. A dendrogram showing the phylogenetic position of strain $\mathrm{AeG}^{\top}$ and its closest relatives. Bootstrap values $>95 \%$ are shown. Bar, $5 \mathrm{nt}$ changes per 100 nt. GenBank accession numbers are given in parentheses. The triangle represents Sporomusa species including: Sporomusa rhizae DSM $16652^{\top}$ (GenBank accession no. AM158322); Sporomusa aerivorans DSM $13326^{\top}$ (AJ506191); Sporomusa ovata DSM 2662 (AJ279800); Sporomusa silvacetica DSM 10669 $^{\top} \quad$ (Y09976); Sporomusa termitida DSM 4440 ${ }^{\top}$ (M61920); Sporomusa malonica DSM 5090 ${ }^{\top}$ (AJ279799); Sporomusa acidovorans DSM $3132^{\top} \quad$ (AJ279798); and Sporomusa sphaeroides DSM $2875^{\top}$ (AJ279801). 
Table 1. Differential characteristics of strain $\mathrm{AeG}^{\top}$ and members of the genus Propionispora

Taxa: 1, Sporolituus thermophilus sp. nov. $\mathrm{AeG}^{\mathrm{T}}$; 2, Propionispora hippei (Biebl et al., 2000); 3, Propionispora vibrioides (Abou-Zeid et al., 2004). +, Positive; -, negative; ND, not determined.

\begin{tabular}{|c|c|c|c|}
\hline Characteristic & 1 & 2 & 3 \\
\hline Source of isolation & $\begin{array}{c}\text { Microbial mats from a thermal } \\
\text { aquifer bore outflow }\end{array}$ & $\begin{array}{c}\text { Sewage sludge, from a municipal } \\
\text { treatment plant }\end{array}$ & Compost \\
\hline Morphology & Curved rods & Vibrio to slightly curved rods & $\begin{array}{l}\text { Vibrio to slightly } \\
\text { curved rods }\end{array}$ \\
\hline Length $(\mu \mathrm{m})$ & $2.0-10.0$ & $2.0-10.0$ & $2.2-6.0$ \\
\hline Width $(\mu \mathrm{m})$ & $0.8-1.0$ & $0.6-1.0$ & 0.6 \\
\hline \multicolumn{4}{|l|}{ Growth temperature $\left({ }^{\circ} \mathrm{C}\right)$} \\
\hline Optimum & 55 & 37 & 37 \\
\hline Range & $45-60$ & $20-50$ & $25-40$ \\
\hline Carbohydrate fermentation & - & + & + \\
\hline Organic acid fermentation & + & ND & - \\
\hline DNA G $+C$ content $(\mathrm{mol} \%)$ & $55.4^{\star}$ & $42.3 \dagger$ & $48.5 \dagger$ \\
\hline Similarity to strain $\mathrm{AeG}^{\mathrm{T}}(\%) \neq$ & 100 & 90.8 & 90.7 \\
\hline
\end{tabular}

${ }^{\star}$ Determined by the thermal denaturation method.

$\dagger$ Determined by HPLC.

$¥$ Similarity based on $16 \mathrm{~S}$ rRNA gene sequence analysis of type strains.

Propionispora by its thermophilic nature, higher DNA $\mathrm{G}+\mathrm{C}$ content and its inability to ferment substrates other than citrate and malate (Table 1). Based on phenotypic differences and the large phylogenetic distance separating strain $\mathrm{AeG}^{\mathrm{T}}$ from other members of the family Veillonellaceae, it is proposed that the novel species Sporolituus thermophilus gen. nov., sp. nov., should be created to accommodate this newly described strain.

\section{Description of Sporolituus gen. nov.}

Sporolituus (Spo.ro.li'tu.us. Gr. fem. n. spora a seed and, in biology, a spore; L. masc. n. lituus a curved rod, crook; N.L. masc. n. Sporolituus a spore-forming, curved rod).

Cells are strictly anaerobic, thermophilic, spore-forming, curved rods that stain Gram-negative. Sluggishly motile. Cells possess peritrichous flagella. 16S rRNA gene sequence analysis indicates that the genus is a member of the family Veillonellaceae and most closely related to the genus Propionispora. The type species is Sporolituus thermophilus.

\section{Description of Sporolituus thermophilus sp. nov.}

Sporolituus thermophilus (ther.mo.phi'lus. Gr. fem. n. thermê heat; Gr. adj. philos loving; N.L. masc. adj. thermophilus heat-loving).

Has the following characteristics in addition to those given for the genus above. Cells are 2.0-10.0 $\times 0.8-1.0 \mu \mathrm{m}$. Growth occurs between 45 and $60{ }^{\circ} \mathrm{C}$ (optimum temperature $55{ }^{\circ} \mathrm{C}$ ) and at $\mathrm{pH} 6.5-8.0$ (optimum $\mathrm{pH}$ 7.0). Utilizes citrate and malate, but not yeast extract, tryptone, peptone, glucose, galactose, mannose, lactose, cellobiose, rhamnose, xylose, sucrose, ribose, fructose, arabinose, maltose, raffinose, mannitol, inositol, dextrin, starch, pectin, chitin, glycerol, ethanol, acetate, propionate, succinate, pyruvate, aspartate, formate, Casamino acids or amyl media. Thiosulfate and sulfite are reduced, but not sulfate, sulfur, nitrate, $\mathrm{Fe}(\mathrm{III})$ or $\mathrm{Mn}(\mathrm{IV})$. Sensitive to chloramphenicol, streptomycin, tetracycline, penicillin and ampicillin. Sensitive to $\mathrm{NaCl}$ concentrations $>1 \%$.

The type strain, $\mathrm{AeG}^{\mathrm{T}}\left(=\mathrm{JCM} 15556^{\mathrm{T}}=\mathrm{KCTC} 5668^{\mathrm{T}}\right.$ ), was isolated from a microbial mat sample from the outflow of a GAB bore (New Lorne Bore) in Queensland, Australia. The genomic DNA $\mathrm{G}+\mathrm{C}$ content of the type strain is $55.4 \pm 1.0 \mathrm{~mol} \%$.

\section{References}

Abou-Zeid, D. M., Biebl, H., Spröer, C. \& Müller, R. (2004). Propionispora hippei sp. nov., a novel Gram-negative, spore-forming anaerobe that produces propionic acid. Int J Syst Evol Microbiol 54, 951-954.

Andrews, K. T. \& Patel, B. K. C. (1996). Fervidobacterium gondwanense sp. nov., a new thermophilic anaerobic bacterium isolated from nonvolcanically heated geothermal waters of the Great Artesian Basin of Australia. Int J Syst Bacteriol 46, 265-269.

Biebl, H., Schwab-Hanisch, H., Spröer, C. \& Lünsdorf, H. (2000). Propionispora vibrioides, nov. gen., nov. sp., a new gram-negative, spore-forming anaerobe that ferments sugar alcohols. Arch Microbiol 174, 239-247.

Brock, T. D. \& Freeze, H. (1969). Thermus aquaticus gen. n. and sp. n., a nonsporulating extreme thermophile. J Bacteriol 98, 289-297.

Habermehl, M. A. (1980). The Great Artesian Basin, Australia. BMR J Aust Geol Geophys 5, 9-38.

Haki, G. D. \& Rakshit, S. K. (2003). Developments in industrially important thermostable enzymes: a review. Bioresour Technol 89, 17-34. 
Head, I. M., Jones, D. M. \& Larter, S. R. (2003). Biological activity in the deep subsurface and the origin of heavy oil. Nature 426, 344-352.

Kanso, S. \& Patel, B. K. C. (2003). Microvirga subterranea gen. nov., sp. nov., a moderate thermophile from a deep subsurface Australian thermal aquifer. Int J Syst Evol Microbiol 53, 401-406.

Kanso, S., Greene, A. C. \& Patel, B. K. C. (2002). Bacillus subterraneus sp. nov., an iron- and manganese-reducing bacterium from a deep subsurface Australian thermal aquifer. Int J Syst Evol Microbiol 52, 869-874.

Lazar, I., Petrisor, I. G. \& Yen, T. F. (2007). Microbial enhanced oil recovery (MEOR). Pet Sci Technol 25, 1353-1366.

Love, C. A., Patel, B. K. C., Nichols, P. D. \& Stackebrandt, E. (1993). Desulfotomaculum australicum, sp. nov., a thermophilic sulfatereducing bacterium isolated from the Great Artesian Basin of Australia. Syst Appl Microbiol 16, 244-251.

Lovley, D. R. (2001). Bioremediation. Anaerobes to the rescue. Science 293, 1444-1446.

Lovley, D. R. \& Phillips, E. J. P. (1986). Organic matter mineralization with reduction of ferric iron in anaerobic sediments. Appl Environ Microbiol 51, 683-689.

Lovley, D. R. \& Phillips, E. J. P. (1988). Novel mode of microbial energy metabolism: organic carbon oxidation coupled to dissimilatory reduction of iron or manganese. Appl Environ Microbiol 54, $1472-1480$.

Marmur, J. \& Doty, P. (1962). Determination of the base composition of deoxyribonucleic acid from its thermal denaturation temperature. J Mol Biol 5, 109-118.

Ogg, C. D. \& Patel, B. K. C. (2009a). Caloramator australicus sp. nov. a thermophilic, anaerobic bacterium from the Great Artesian Basin of Australia. Int J Syst Evol Microbiol 59, 95-101.

Ogg, C. D. \& Patel, B. K. C. (2009b). Thermotalea metallivorans gen. nov., sp. nov., a thermophilic, anaerobic bacterium from the Great Artesian Basin of Australia aquifer. Int J Syst Evol Microbiol 59, 964-971.

Ogg, C. D. \& Patel, B. K. C. (2009c). Fervidicola ferrireducens gen. nov., sp. nov., a thermophilic anaerobic bacterium from geothermal waters of the Great Artesian Basin, Australia. Int J Syst Evol Microbiol 59, 1100-1107.
Patel, B. K. C., Morgan, H. W. \& Daniel, R. M. (1985a). A simple and efficient method for preparing and dispensing anaerobic media. Biotechnol Lett 7, 277-288.

Patel, B. K. C., Morgan, H. W. \& Daniel, R. M. (1985b). Fervidobacterium nodosum gen. nov. and spec. nov., a new chemoorganotrophic, caldoactive, anaerobic bacterium. Arch Microbiol 141, 63-69.

Ramamoorthy, S., Sass, H., Langner, H., Schumann, P., Kroppenstedt, R. M., Spring, S., Overmann, J. \& Rosenzweig, R. F. (2006). Desulfosporosinus lacus sp. nov., a sulfate-reducing bacterium isolated from pristine freshwater lake sediments. Int J Syst Evol Microbiol 56, 2729-2736.

Redburn, A. C. \& Patel, B. K. C. (1994). Desulfovibrio longreachii sp. nov., a sulfate-reducing bacterium isolated from the Great Artesian Basin of Australia. FEMS Microbiol Lett 115, 33-38.

Sørensen, J. (1982). Reduction of ferric iron in anaerobic, marine sediment and interaction with reduction of nitrate and sulfate. Appl Environ Microbiol 43, 319-324.

Spanevello, M. D. (2001). The phylogeny of prokaryotes associated with Australia's Great Artesian Basin. PhD thesis, School of Biomolecular and Physical Science, Griffith University, Brisbane, Australia.

Spanevello, M. D. \& Patel, B. K. C. (2004). The phylogenetic diversity of Thermus and Meiothermus from microbial mats of an Australia subsurface aquifer runoff channel. FEMS Microbiol Ecol 50, 63-73.

Spanevello, M. D., Yamamoto, H. \& Patel, B. K. C. (2002). Thermaerobacter subterraneus sp. nov., a novel aerobic bacterium from the Great Artesian Basin of Australia, and emendation of the genus Thermaerobacter. Int J Syst Bacteriol 52, 795-800.

Spratt, H. G., Jr, Siekmann, E. C. \& Hodson, R. E. (1994). Microbial manganese oxidation in salt marsh surface sediments using a leuco crystal violet manganese oxide detection technique. Est Coast Shelf Sci 38, 91-112.

Wolin, E. A., Wolin, M. J. \& Wolfe, R. S. (1963). Formation of methane by bacterial extracts. J Biol Chem 238, 2882-2886.

Zeikus, J. G., Hegge, P. W. \& Anderson, M. A. (1979). Thermoanaerobium brockii gen. nov. and sp. nov., a new chemoorganotrophic, caldoactive, anaerobic bacterium. Arch Microbiol 122, 41-48. 